\title{
Assessing Reservoir Operating Requirements in Changing Hydrological Conditions: A Case Study of Mietków Dam
}

\author{
Stanisław Kostecki*, Jerzy Machajski \\ Wrocław University of Science and Technology, Faculty of Civil Engineering
}

Received: 24 August 2017

Accepted: 21 November 2017

\begin{abstract}
Climate change in recent years has caused considerable intensification of rainfall, and as a consequence an increase in flood waves flow rate. This article presents the verifying method of the dam overtopping risk under conditions of enlarged volumetric flood flow rates inflowing the storage reservoir. Values of the flow rate peaks were determined on the hydrological observations basis. The course of the hypothetical flood wave hydrograph was determined on the normalization and averaging basis of the 6 historical flood wave hydrographs. The flood routing analysis through the reservoir was numerically performed, with the assumptions of Puls's method, for 6 scenarios with 2 flood flow rates and for 3 initial water levels in the reservoir. On the obtained results basis the dam overtopping hazard level was determined, and the necessity for reservoir water management changes was pointed out.
\end{abstract}

Keywords: storage reservoir, wave transformation, outflow devices, water management, reservoir safety

\section{Introduction}

In the last 2 decades the visible effects of global warming have been characterised by heavy rainfalls leading to greater volumetric floods than in previous years, both during the rainy season and in the form of flash floods [1-4]. If a storage reservoir is situated in the path of such flood waves, there is a risk of dam overtopping due to insufficient spillway discharge [5-8]. According to statistics, the biggest risk for earth dams is flooding, and $34 \%$ of earth dam disasters in the world have been caused by breaching of the dam body because of overtopping [8-11]. A flood wave caused by the failure of a large dam is usually of higher velocity and discharge

*e-mail: Stanislaw.Kostecki@pwr.edu.pl than a natural flood wave, meaning that such waves carry a higher cost, both financially and in terms of risk to human life. For this reason, any dam older than 10 years should be verified regarding its ability to withstand flood waves $[1-2,4,25]$.

The risk of a catastrophic dam breach is traditionally estimated based on probable maximum flood (PMF). PMF is determined on the basis of probable maximum precipitation (PMP) for a specific time period, in order to estimate the potential size (discharge and volume) of cumulative flood waves at the location of the dam. A review of methods used in practice was made by Jothityangkoon [2], who aimed his investigations at defining the influence of climate and land development changes on extreme floods under different types or patterns of PMPs, antecedent moisture conditions, increased rainfall under climate change, and deforestation. He developed 
an extreme flood estimation model based on long-term water balance and runoff-routing distribution models. Next he demonstrated that climate and land development changes can cause significant changes to the magnitude of extreme floods. Similar results were gathered by Yigzaw [12], who found that it is crucial to consider the potential impacts of land development/land cover (LULC)-driven changes in extreme precipitation for improving the functional overload capacity of dams. Dams' impact on local land development, land cover, and other activity should be considered in a dynamic way such that current and future influences are included in risk assessment and mitigation measures. Kang [1] calculated PMF using the streamflow synthesis and reservoir regulation (SSARR) model based on precipitation and temperature projected by the community climate system model (CCSM) and the Seoul national university regional climate model (SNURCM) for the climate change scenario, and obtained an average streamflow that increased by $38.7 \%$, and whose variability increased by $14.3 \%$.

Goodarzi [13] presented a risk analysis based on uncertainty approaches including frequency analysis of floods and wind speeds, reservoir routing, and the integration of prevailing winds. He calculated the highest water level in the reservoir in order to evaluate the percentage of increased risk of overflowing at different water levels, wind speeds, and flood frequencies. Lee [3] presented the impact of increase in the frequency of extreme hydrological events caused by climate change and used a stochastic approach to quantify the risk of dam overtopping, including siltation of the reservoir.

Receanu et al. [14] proposed the new method of the flood hydrograph estimation (PMF) in Switzerland using 3 main contributions integrated into a single computational model. The first was based on a method of spatial-temporal distribution of PMP using clouds and winds, the second involved surface and groundwater flow to obtain the shape of the hydrograph at the outlet, and the third calculated the influence of snowmelt on flow. Lagos-Zúñiga and Vargas [15] proposed a similar approach to determine the potential effects of climate change on PMP/PMF calculations for the future period of 2045-2065. Their calculations involved analyses of statistical uncertainty due to temporal distribution of storms, previous moisture conditions in the river basin, and the confidence interval of the maximization factors. Micovic [16] identified different uncertainties in estimating PMP and presented the new methodology for assessing PMP. He presented the results of the PMP uncertainty analysis including in-place moisture maximization, surface dew-points, storm horizontal transposition, storm center location, and storm efficiency, as well as their respective likelihood functions for the La Joie River basin in Canada. He compared the result with the traditional single-value PMP estimate as well as the resulting PMF hydrographs. Gądek [17] calculated PMF using probability curves developed on the river multiyear measurements basis of water elevation and flow at gauging stations.

Adapting reservoirs to larger flood waves requires either a change in reservoir storage and a change in reservoir water management; an increase in reservoir flow capacity by designing, for example, an additional emergency spillway; or raising the height of the dam to increase reservoir storage. The first solution is the least expensive but its effectiveness is also severely limited. Moreover, reducing the operational capacity of the reservoir to collect increased volume of the flood reduces the overall usefulness of the dam. In practice, the second solution is usually the least effective. The third may be the most costly, and can often be impossible to implement, but it may be the most beneficial when one considers the losses incurred by floods [4].

As a consequence of climate change, in 1997 Polish authorities changed the regulations [18], including technical and calculating requirements, for hydraulic structures. Larger flood waves must be taken into consideration as well as a failure threat analyses. As a result, many dams constructed before 1997 may have insufficient spillway solutions - both in terms of the technologies used during their construction and spillway discharge.

Analysing the flood routing through the river, one should consider hydrological conditions of the river basin, the operational characteristics of the spillways, and reservoir storage. For example, if reservoir storage is small relative to the flood volume, then flood peak discharge is the primary concern. Conversely, if the reservoir has very large storage, then runoff volume and total storm precipitation are the primary concerns. Many dam and reservoir projects are sensitive to a combination of maximum intensities and total precipitation [16].

The aim of this publication points out that climate change can resulted in essentially increasing flood flow rates. For these increased flow rates, analyzing flood routing through a reservoir ought to be done, especially for dam crest overtopping risk estimation. The dam crest overtopping probable risk results, for example, from insufficient discharge of the hydraulic structure. This was realized in the example of the storage

Table 1. Calculated discharges at Mietków Dam before and after regulatory changes.

\begin{tabular}{|c|c|c|c|c|}
\hline \multirow{2}{*}{ Calculated discharges } & \multicolumn{2}{|c|}{ Design discharge } & \multicolumn{2}{c|}{ Control discharge } \\
\cline { 2 - 5 } & $p_{\mathrm{m}}(\%)$ & $Q_{\mathrm{m}}\left(\mathrm{m}^{3} \mathrm{~s}^{-1}\right)$ & $p_{\mathrm{k}}(\%)$ & $Q_{\mathrm{k}}\left(\mathrm{m}^{3} \mathrm{~s}^{-1}\right)$ \\
\hline Value at time of construction & 0.3 & 366 & 0.05 & 647 \\
\hline After 1997 regulatory changes [8] & 0.1 & 548 & 0.02 & 805 \\
\hline
\end{tabular}


Table 2. Mietków Reservoir overflow structure discharges.

\begin{tabular}{|c|c|c|c|}
\hline $\begin{array}{c}\text { Discharge } \\
\text { capacity } \\
\left(\mathrm{m}^{3} \mathrm{~s}^{-1}\right)\end{array}$ & $\begin{array}{c}\text { NWL 170,60 } \\
(\mathrm{m} \text { a.s.1. })\end{array}$ & $\begin{array}{c}\text { Max WL } \\
172,30 \\
(\mathrm{~m} \text { a.s.1. })\end{array}$ & $\begin{array}{c}\text { Max EL } \\
173,60 \\
(\mathrm{~m} \text { a.s.1. })\end{array}$ \\
\hline Spillways & 60 & 268 & 470 \\
\hline Outlets & 170 & 180 & 190 \\
\hline
\end{tabular}

reservoir Mietków on the Bystrzyca River, for which the calculating procedure of the flood wave hydrographs and resulting discharges is presented. For these hydrographs, an analysis of their routing through the reservoir was done. Calculations were completed for several reservoir water levels to point out that existing hydraulic structures do not guarantee object safety.

\section{Material and Methods}

Mietków Reservoir on the Bystrzyca River, with a total water storage capacity of $88 \mathrm{mln} \mathrm{m}^{3}$, was built in 1986 in order to: protect the river valley below the dam under flooding, supply the Odra River Waterway in the dry season, allow for the exploitation of minerals, provide electric power from a small hydro-electric power station at the dam, and improve recreational and fishing activities within the reservoir area [19]. Mineral exploitation has, over time, led to a small increase in the overall storage of the reservoir. As a result of regulatory changes binding for hydraulic structures [18], the dam has been changed from the lower class II to the higher class I of hydroengineering objects, resulting in a significant increase in the calculated flows summarised in Table 1.

The total length of the earthfill dam is $3,220 \mathrm{~m}$ (at its crest). The reservoir's surface area at maximum reservoir

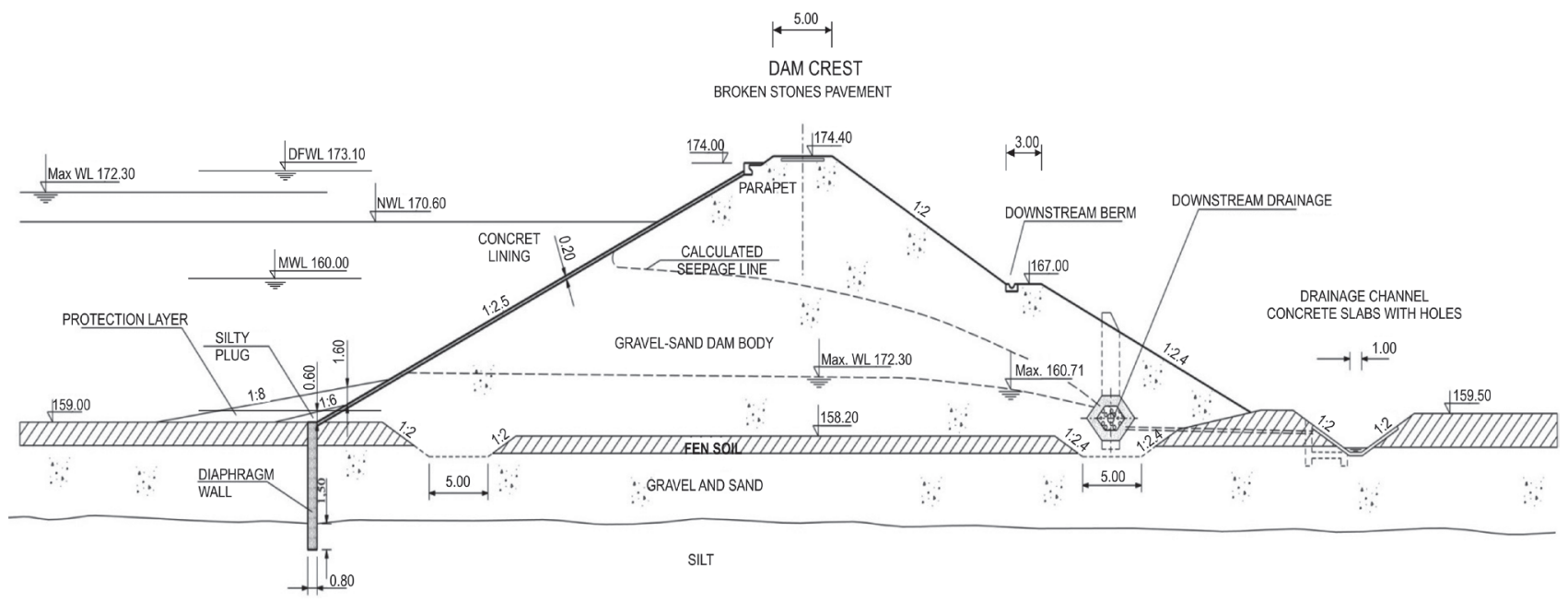

Fig. 1. Cross-section of Mietków storage reservoir earthfill dam.

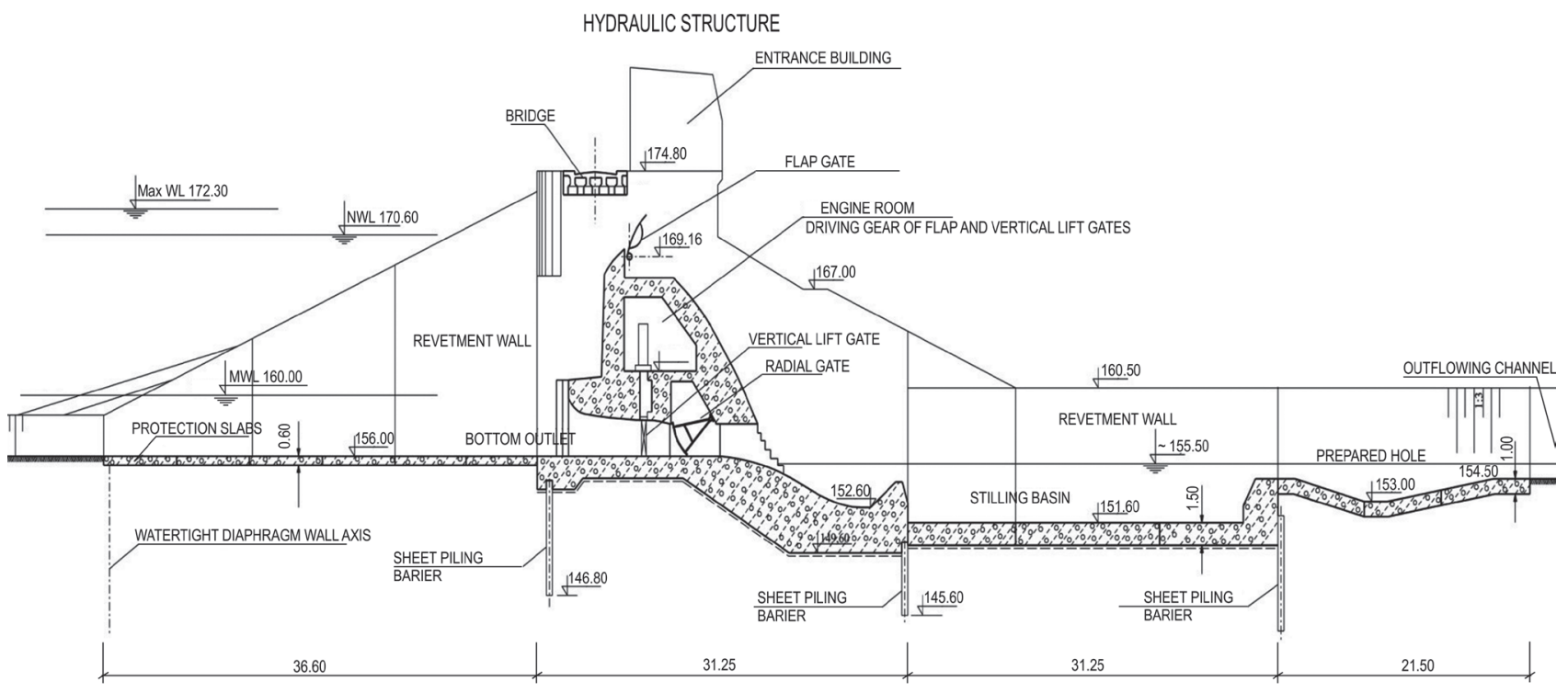

Fig. 2. Cross-section of Mietków reservoir hydraulic structure. 
Table 3. Storage levels in reservoir and corresponding design capacities, and capacities after measurements carried out in 2008.

\begin{tabular}{|c|c|c|c|c|c|c|c|c|}
\hline $\begin{array}{c}\text { Reservoir water levels and } \\
\text { resultant storage }\end{array}$ & $\begin{array}{c}\text { Min WL } \\
\mathrm{m} \text { a.s.1. }\end{array}$ & $\begin{array}{c}\mathrm{V} \\
\mathrm{mln} \mathrm{m}^{3}\end{array}$ & $\begin{array}{c}\mathrm{NWL} \\
\mathrm{m} \text { a.s.1. }\end{array}$ & $\begin{array}{c}\mathrm{V} \\
\mathrm{mln} \mathrm{m}^{3}\end{array}$ & $\begin{array}{c}\text { Max WL } \\
\mathrm{m} \text { a.s.1. }\end{array}$ & $\begin{array}{c}\mathrm{V} \\
\mathrm{mln}^{3}\end{array}$ & $\begin{array}{c}\text { Max EL } \\
\mathrm{m} \text { a.s.1. }\end{array}$ & $\begin{array}{c}\mathrm{V} \\
\mathrm{mln}^{3}\end{array}$ \\
\hline Design value & 160.00 & 3.71 & 171.80 & 62.747 & 172.30 & 70.561 & 173.60 & - \\
\hline $\begin{array}{c}\text { After measurement } \\
\text { in 2008 }\end{array}$ & 160.00 & 2.11 & 170.60 & 66.26 & 172.30 & 76.98 & 173.60 & 87.84 \\
\hline
\end{tabular}

water level (Max WL $=172.30 \mathrm{~m}$ a.s.l. in Kronstadt) is $8.35 \mathrm{~km}^{2}$, and the resultant backwater range is $5 \mathrm{~km}$ long. The homogeneous dam body was built from gravel and sand-gravel extracted from the impounding reservoir space. The highest point of the dam is $17 \mathrm{~m}$ and width of the dam at the base is about $80 \mathrm{~m}$, while the dam crest is $5.0 \mathrm{~m}$ wide (Fig. 1). The dam body was waterproofed with concrete slabs while the subgrade under the dam was sealed with a clay-concrete cut-off bed extending down to the clay stratum. The reservoir hydraulic structures are: an overflow with 2 spans, each $12.50 \mathrm{~m}$ wide and with flap gates on their crests, and a bottom outlet consisting of three conduits of $1.90 \times 2.20 \mathrm{~m}$ parameters, closed with radial gates on the tailwater side (functioning as the main gates), and on the headwater side with vertical lift gates (constituting the emergency gates). The reservoir hydraulic structure is in a monolithic concrete structure built in the dam body (Fig. 2). Water from the hydraulic structure passes to a stilling basin with a rectangular cross-section, of following dimensions: width $29.0 \mathrm{~m}$, length $31.25 \mathrm{~m}$, and depth $2.90 \mathrm{~m}$, and then through a 1,581 m-long outflow channel to the Bystrzyca River.

The capacity of the hydraulic structure (with the flap gates fully opened) as a function of the reservoir water level was calculated from the formulas given in the literature [20-21] (Table 2). The total discharge of the

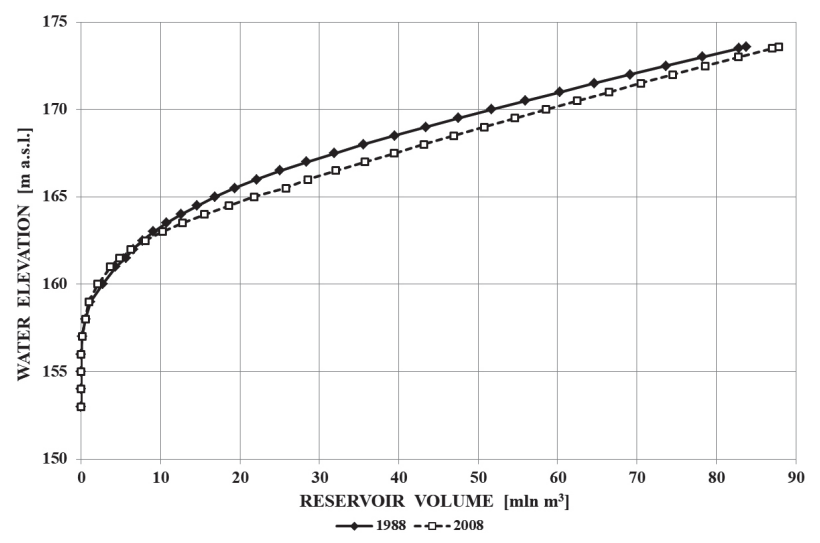

Fig. 4. Changes in total reservoir storage, 1988-2008.

existing overflow structure amounts to $648 \mathrm{~m}^{3} \mathrm{~s}^{1}$, and the reservoir hydraulic structure discharge curve is shown in Fig. 3.

The flow discharges of the Bystrzyca River channel downstream of the Mietków storage reservoir are as follows. The allowable runoff (which does not cause significant damage to the river channel and the adjacent areas) amounts to $40 \mathrm{~m}^{3} \mathrm{~s}^{-1}$; the flow amounting to $120 \mathrm{~m}^{3} \mathrm{~s}^{-1}$ is regarded as the flood runoff and is the

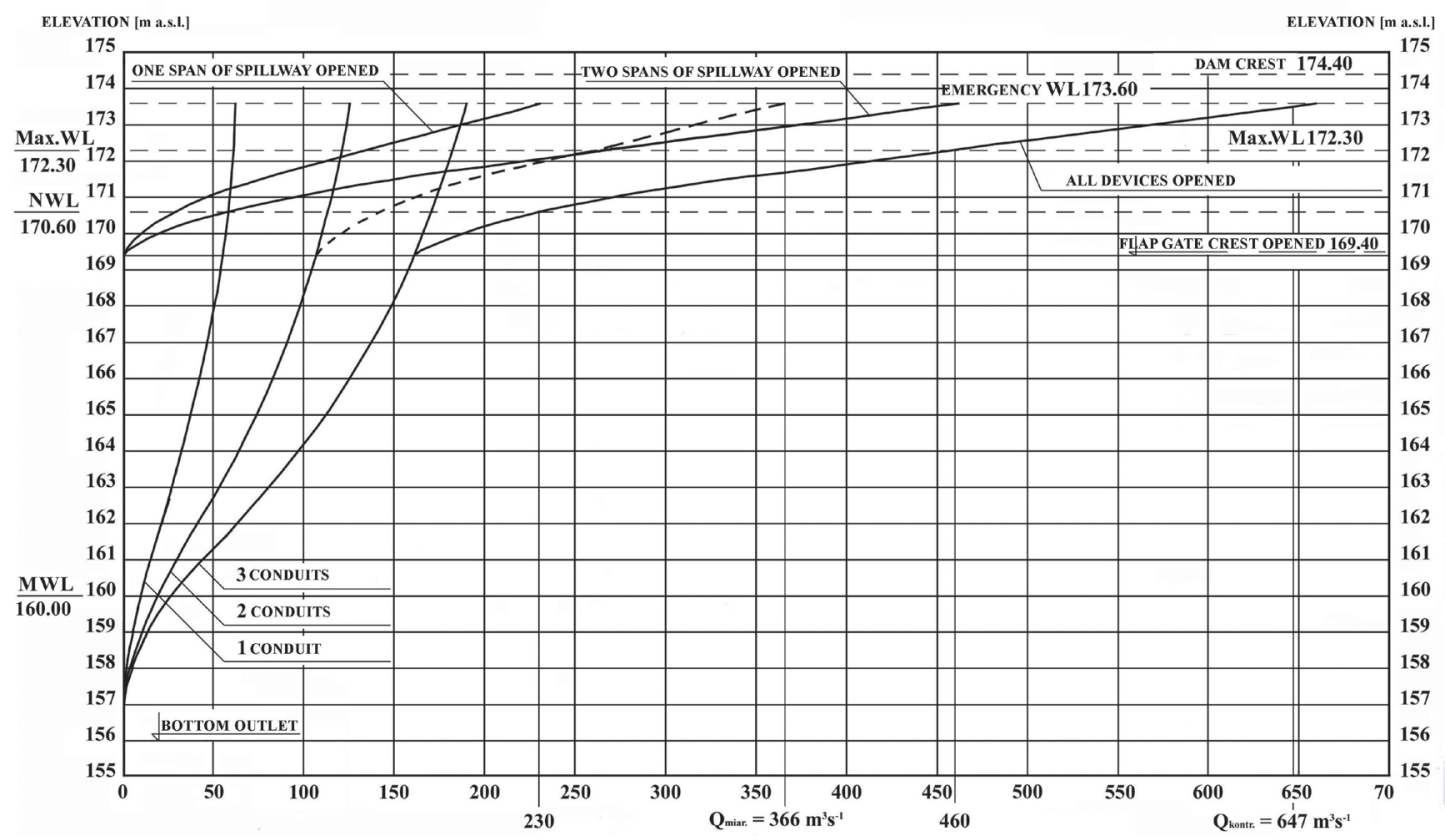

Fig. 3. Hydraulic structure total discharge curves at full opening of installed gates. 
Table 4. Discharges with a given probability of exceedance $\left(\mathrm{Q}_{\operatorname{maxp} \%}\right)$ in the cross-section of Mietków Reservoir.

\begin{tabular}{|c|c|c|c|c|c|c|c|c|}
\hline $\mathrm{p} \%$ & 50 & 10 & 1 & 0,5 & 0,3 & 0,1 & 0,05 & 0,02 \\
\hline Without a mean estimation error $\delta, \mathrm{m}^{3} \mathrm{~s}^{-1}$ & 40.1 & 117 & 285 & 352 & 409 & 548 & 651 & 805 \\
\hline With a mean estimation error $\delta, \mathrm{m}^{3} \mathrm{~s}^{-1}$ & & & & 436 & 511 & 700 & 841 & 1056 \\
\hline
\end{tabular}

flow limit for flood damage, above which the material losses increase rapidly. Flows greater than $120 \mathrm{~m}^{3} \mathrm{~s}^{-1}$ are regarded as catastrophic. The characteristic storage parameters of the reservoir, based on the 1986 data and 2008 bathymetric measurements [22], are presented in Table 3 and in Fig. 4. After 2008, a decision was made to lower the normal water level (NWL) by $1.20 \mathrm{~m}$, whereby the reservoir flood control storage increased from 7.81 to $13.72 \mathrm{M} \mathrm{m}^{3}$.

The Bystrzyca River, with a total length of $95.2 \mathrm{~km}$ and catchment area $\mathrm{A}=1,767.8 \mathrm{~km}^{2}$, is a leftbank tributary of the Odra River with its mouth in the $266.5 \mathrm{~km}$ mark of the Odra course. It has its source in the eastern part of the Sowie Mountains at an elevation of about $690 \mathrm{~m}$ a.s.l. The average gradient of the catchment ranges from $21.2 \%$ in the upper reaches to $0.53 \%$ in the lower reaches. The river network density amounts to about $0.55 \mathrm{~km}^{-1}$ and the forestation ratio ranges from $54 \%$ in the mountains to $15 \%$ in the lower reaches of the river. In the $75.2 \mathrm{~km}$ of the river course there is the dam of the Lubachów Reservoir with the total storage of $12 \mathrm{M} \mathrm{m}^{3}$. Downstream of this reservoir the Bystrzyca River Valley widens to $1.5-3 \mathrm{~km}$ with a flat-bottomed valley character. Along this stretch the Bystrzyca is supplied by Złotnica, Witoszów Stream, and Jabłonie left-bank tributaries, and a major right-bank tributary - the Piława River. Mietków Reservoir is located at 45.0-50.5 km of the Bystrzyca's course.

Calculation flows for Mietków were determined using the extrapolation method, transferring observations from Krasków water gauge station to the dam cross-section using Formula (1):

$$
Q_{Z}=Q_{K}\left(A_{Z} / A_{K}\right)^{2 / 3}=1,34 Q_{K}
$$

... where $Q_{Z}$ and $A_{Z}$, respectively, are the flow and the catchment area in the cross-section of the dam; and $Q_{K}$ and $A_{K}$, respectively, are the flow and the catchment area in the Krasków station. The following values were obtained (Polish abbreviations): lowest flow $\mathrm{NNQ}=0.175 \mathrm{~m}^{3} \mathrm{~s}^{-1}$, average low flow $\mathrm{SNQ}=0,712 \mathrm{~m}^{3} \mathrm{~s}^{-1}$, average annual flow SSQ $=4.56 \mathrm{~m}^{3} \mathrm{~s}^{-1}$, average large flow SWQ $=68.0 \mathrm{~m}^{3} \mathrm{~s}^{-1}$, and maximum flow $\mathrm{WWQ}=198 \mathrm{~m}^{3} \mathrm{~s}^{-1}[19]$.

Input data for the hydraulic structure capacity calculations and the flood waves routing through the reservoir, were discharges with a given probability of exceedance. Their values were determined on the basis of the multiannual observation sequences for Krasków station. The sequences were examined with regard to genetic and statistical heterogeneity. The analysis showed that they satisfied the homogeneity conditions. The maximum annual flows were determined on the basis of the measured maximum annual water levels, which were assigned flows from the current reliable stage - discharge curves. The parameters of the probability distribution function were estimated using the maximum likelihood method. Discharges to the Mietków Dam cross-section were calculated using the scaled Krasków station discharge values from Relation (1) (Table 4).

Considering that the proper choice of the control flow has a significant bearing on the assessment of dam safety, Table 4 compares the flow values with and without mean estimation error $\delta$. According to the Environment Ministry Regulation of 2007 [18], the control flow for rivers and mountain streams should be determined by adding mean estimation error $\delta$ to the calculated flow value at $t_{\alpha}=1$ and the confidence level of 0.84 . Since Lubachów reservoir situated in the upstream part of the catchment to some extent alters the character of the Bystrzyca, in the calculations one should use the control flow without adding mean estimation error. However, the right-bank tributary of the Bystrzyca upstream of the reservoir, i.e. the Piława River (classified as a mountain water course) poses a significant problem since in the period of flood waves it carries volumetrically large flows (Table 5). Therefore, one should consider taking larger flows into account.

Hypothetical waves for the Mietków Reservoir were constructed on the basis of the real high flow hydrographs observed in the cross-section of Krasków station on the Bystrzyca River in 1964-2002. The hydrographs have been determined through analysis of the highest flows, where the limit flow corresponded to the warning stage [23].

Table 5. Discharges with assigned exceedance probability $\left(\mathrm{Q}_{\operatorname{maxp} \%}\right)$ for Mościsko water gauge station on the Piława River.

\begin{tabular}{|c|c|c|c|c|c|c|c|c|}
\hline $\mathrm{p} \%$ & 50 & 10 & 1 & 0,5 & 0,3 & 0,1 & 0,05 & 0,02 \\
\hline Without a mean estimation error, $\mathrm{m}^{3} \mathrm{~s}^{-1}$ & 19.2 & 60.0 & 120 & 139 & 152 & 182 & 200 & 225 \\
\hline With a mean estimation error, $\mathrm{m}^{3} \mathrm{~s}^{-1}$ & & & & 164 & 180 & 216 & 239 & 269 \\
\hline
\end{tabular}


Table 6. Design and control flows with corresponding wave volumes.

\begin{tabular}{|c|c|c|c|c|}
\hline Probability & \multicolumn{2}{|c|}{ Design $p_{\mathrm{m}}(\%)=0.1$} & \multicolumn{3}{|c|}{ Control $p_{\mathrm{k}}(\%)=0.02$} \\
\hline Discharge & $Q_{\mathrm{m}}\left(\mathrm{m}^{3} \mathrm{~s}^{-1}\right)$ & $V\left(\mathrm{M} \mathrm{m}^{3}\right)$ & $Q_{\mathrm{k}}\left(\mathrm{m}^{3} \mathrm{~s}^{-1}\right)$ & $V\left(\mathrm{M} \mathrm{m}^{3}\right)$ \\
\hline Without the estimation error $\delta$ & 548 & 165.75 & 805 & 243.71 \\
\hline With the estimation error $\delta$ & 700 & 211.79 & 1056 & 319.53 \\
\hline
\end{tabular}

The hypothetical waves were calculated using a method that consists in selecting 6 hydrographs from the highest river flows registered in Kraskow station, for which normalization with respect to the high flow duration and the flow rate was carried out. The normalized waves were averaged whereby the shape of a reference wave with peak $Q_{\mathrm{s}}=1$, concentration time $t_{\mathrm{k}}$ $=1$, and total high flow duration $T \mathrm{~s}=5$ were obtained. The design waves were obtained by scaling the reference wave to the maximum flows with the given probability of exceedance. Then the calculated wave hydrographs were transformed to the Mietków Dam location, whereby the design wave and the control wave (Fig. 5) with the peaks shown in Table 1 were obtained. The volumes of the waves are shown in Table 6.

Preliminary numerical analyses of the control wave with the estimation error showed no possibility of the safe passing of this flow through the reservoir without upgrading the existing overflow structures, even at the lowest reservoir filling water level (the dead storage water level of $160.00 \mathrm{~m}$ a.s.l). Therefore, in further consideration of the operational safety of the reservoir with its current discharge capacities, the design wave and the control wave were assumed without the estimation error.

The flood wave routing through the reservoir was carried out using a method exploiting the continuity equations in the differential form (1) [24]:

$$
\frac{\partial Q}{\partial x}+\frac{\partial A}{\partial t}=0
$$

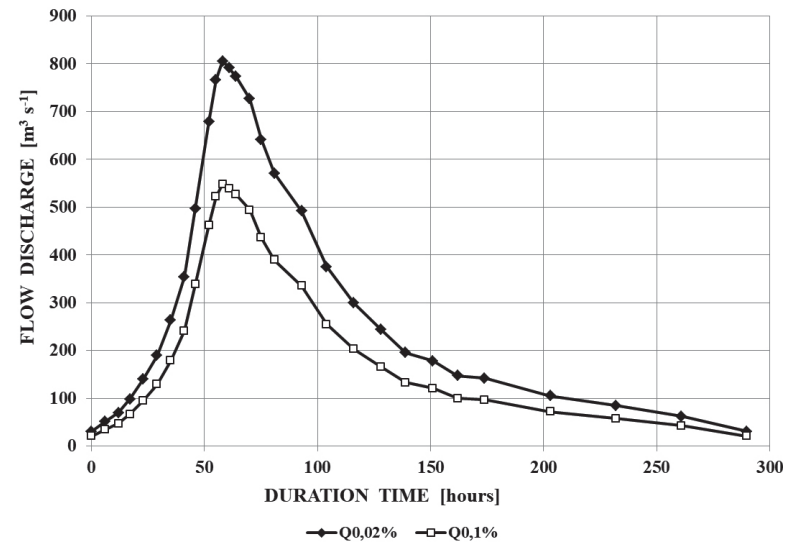

Fig. 5. Hypothetical flood waves for Mietków Reservoir. ...where $Q$ is water flow $\left(\mathrm{m}^{3} \mathrm{~s}^{-1}\right), x$ is a coordinate consistent with the direction of water flow (m), $A$ is the flow surface area $\left(\mathrm{m}^{2}\right)$, and $t$ is time (s).

After its integration in a range from $x_{1}$ to $x_{2}$ and proper transformation, Equation (2) assumes the following form (where the integer value represents the volume of the water stored in the reservoir or discharged from it):

$$
Q\left(x_{1}\right)-Q\left(x_{2}\right)+\frac{d}{d t} \int_{x_{1}}^{x_{2}} A d x=0
$$

$\ldots$ and further

$$
Q\left(x_{1}\right)=Q\left(x_{2}\right)+\frac{\Delta V}{\Delta t}
$$

...where: $x_{1}$ coordinates at the reservoir beginning, $x_{2}$ coordinates at the reservoir end, $Q\left(x_{1}\right)$ is the reservoir water inflow $\left(\mathrm{m}^{3} \mathrm{~s}^{-1}\right), Q\left(x_{2}\right)$ is the reservoir water outflow $\left(\mathrm{m}^{3} \mathrm{~s}^{-1}\right)$, and $\Delta \mathbf{V} / d t$ is the change in water volume in the reservoir over time.

An analysis of the flood wave routing through the reservoir was made using the assumptions of the Puls method (the inlet-storage-outlet method) [23]. The following cases and assumptions were adopted for flood wave routing:

- Wave $Q_{m}$ : case $\mathbf{A}$ - one conduit of the bottom outlet and one span of an overflow out of operation.

- Wave $\mathrm{Q}_{\mathrm{m}}$ : case $\mathbf{B}$ - all the reservoir overflow structures in operation.

- Wave $\mathrm{Q}_{\mathrm{k}}$ : case $\mathbf{C}$ - all the reservoir overflow structures in operation.

- The design flood level of the reservoir (DFWL) corresponding to wave $\mathrm{Q}_{\mathrm{m}}$ is $173.10 \mathrm{~m}$ a.s.l., hence the design freeboard is $1.30 \mathrm{~m}$.

- The control flood level of the reservoir (CFWL) corresponding to wave $\mathrm{Q}_{\mathrm{k}}$ is $174.10 \mathrm{~m}$ a.s.1., hence the control freeboard is $0.30 \mathrm{~m}$.

- Class I hydraulic structure importance, 3 initial water levels in the reservoir:

○ $\mathbf{1 7 0 . 6 0} \mathbf{m}$ a.s.l. (normal storage water level NWL)

○ $\quad \mathbf{1 6 9 . 4 0} \mathbf{m}$ a.s.l. (the spillway crest level when the flap gate is fully opened)

$\quad \mathbf{1 6 0 . 0 0} \mathbf{~ m}$ a.s.l. (minimum storage water level MWL corresponding to reservoir dead storage) 


\section{Results and Discussion}

On the basis of the analysis of reservoir flood routing for the discharge rates with estimating error $\delta$ (i.e., $\mathrm{Q}_{\mathrm{m}}$

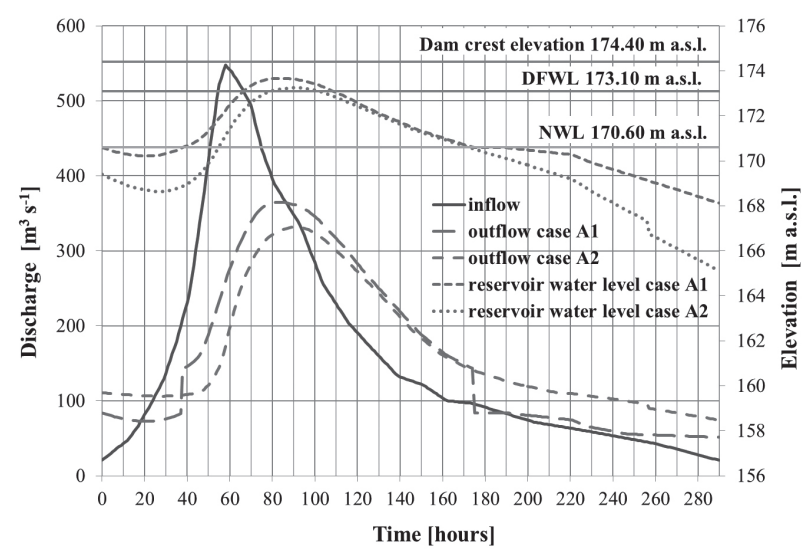

Fig. 6. Reservoir routing of $\mathrm{Q}_{0,1 \%}$, the initial water level (IWL) in the reservoir: 170.60 (case A1) and 169.40 (case A2).

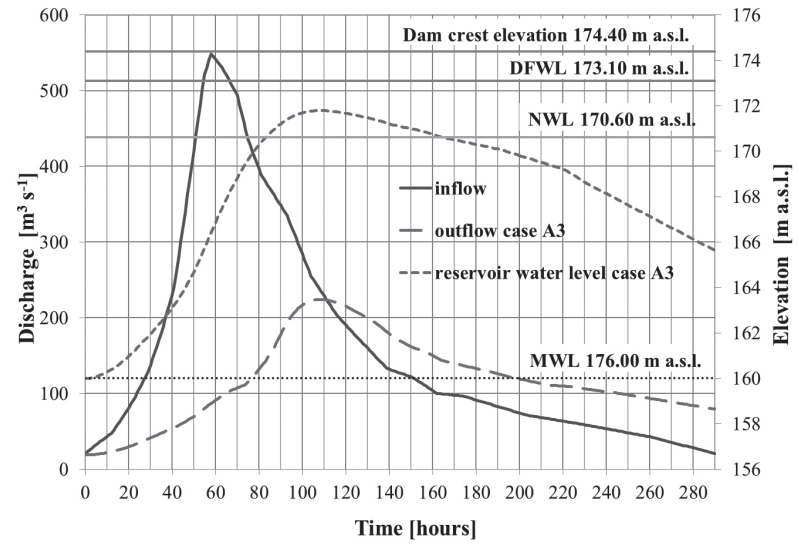

Fig. 7. Reservoir routing of design wave $\mathrm{Q}_{0,1 \%}$, the IWL in the reservoir: 160.00 (case A3).

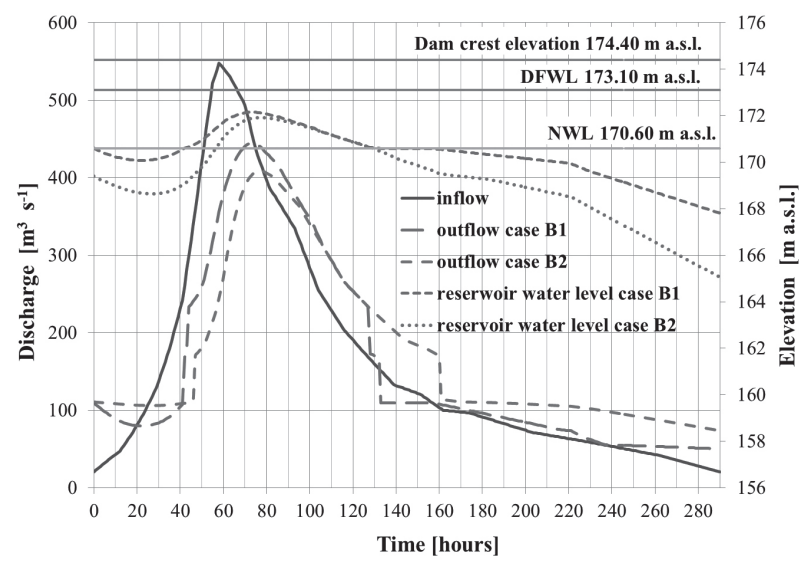

Fig. 8. Reservoir routing of $\mathrm{Q}_{0,1 \%}$, the IWL in the reservoir: 170.60 (case B1) and 169.40 (case B2).
$=700 \mathrm{~m}^{3} \mathrm{~s}^{-1}$ and $\mathrm{Q}_{\mathrm{k}}=1,056 \mathrm{~m}^{3} \mathrm{~s}^{-1}$ ), it was stated that for every initial reservoir water level the dam crest has been overtopped. The calculation results in the form of timevariable reservoir water levels and the corresponding discharges without an estimation error are presented in Figs 6-11.

An analysis of the results (Fig. 6) showed that only for case A1 was the safe dam crest elevation requirement (freeboard) significantly exceeded, i.e., by $57 \mathrm{~cm}$. In case A2 the safe dam crest elevation requirement is exceeded by merely $4 \mathrm{~cm}$. In each of the cases, the reservoir outflow exceeded the limit value for flood damage downstream of the reservoir, amounting to $120 \mathrm{~m}^{3} \mathrm{~s}^{-1}$, i.e., $364.90 \mathrm{~m}^{3} \mathrm{~s}^{-1}$ for case A1 and $331.72 \mathrm{~m}^{3} \mathrm{~s}^{-1}$ for case A2.

The calculation results for case A3 are presented in Fig. 7, which shows that the maximum water level did not exceed the relevant freeboard of $1.30 \mathrm{~m}$. The freeboard obtained from the calculation equals $2.62 \mathrm{~m}$. The reservoir outflow equaling $223.94 \mathrm{~m}^{3} \mathrm{~s}^{-1}$ is less than the storage reservoir inflow that equals $548 \mathrm{~m}^{3} \mathrm{~s}^{-1}$.

Fig. 8 shows the calculation results for cases B1 and B2. The reservoir water levels are much below the

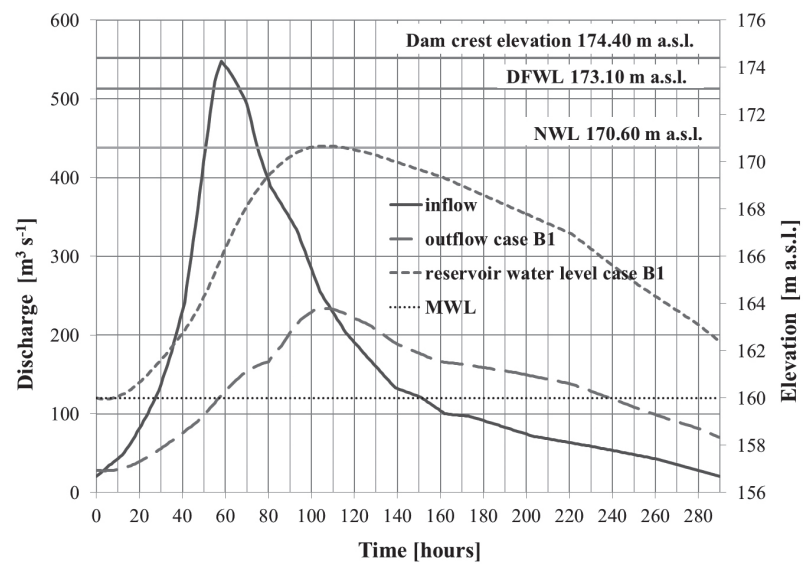

Fig. 9. Reservoir routing of $\mathrm{Q}_{0,1 \%}$, the IWL in the reservoir: 160.00 (case B3).

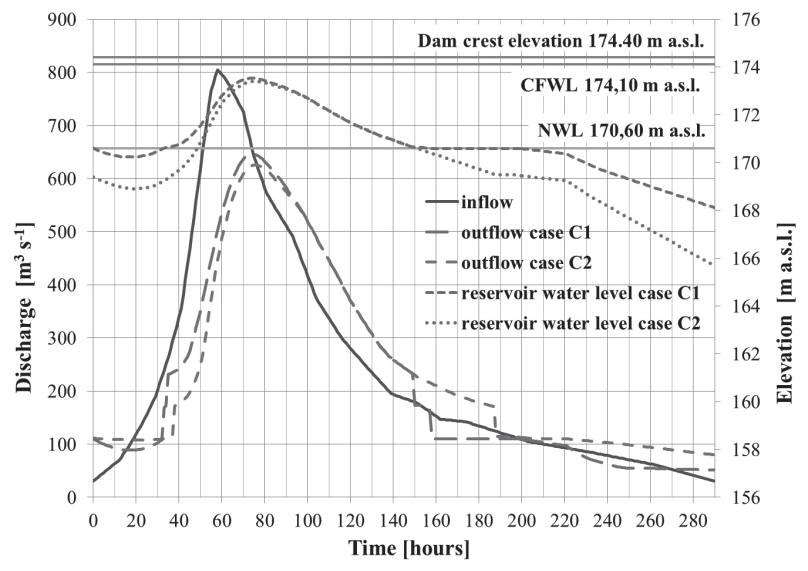

Fig. 10. Reservoir routing of $\mathrm{Q}_{0,02 \%}$, the IWL in the reservoir: 170.60 (case $\mathrm{C} 1$ ) and 169.40 (case C2). 


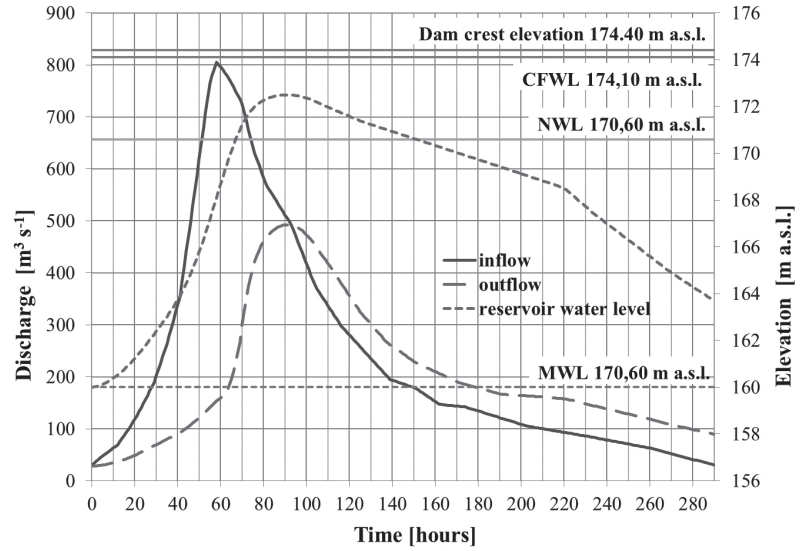

Fig. 11. Reservoir routing of $\mathrm{Q}_{0,02 \%}$, the IWL in the reservoir: 160.00 (case C3)

adequate freeboard limit. However, the resultant outflows are more adverse than in the A3 and equal $444.46 \mathrm{~m}^{3} \mathrm{~s}^{-1}$ for case B1 and $409.19 \mathrm{~m}^{3} \mathrm{~s}^{-1}$ for case B2, producing the essential risk of damage on the adjacent areas.

Calculating case B3 (Fig. 9) shows an essential reduction of the reservoir outflow to the value of $233.87 \mathrm{~m}^{3} \mathrm{~s}^{-1}$, and the essential freeboard equals $3.73 \mathrm{~m}$.

Fig. 10 illustrates calculation results of the control wave $\mathrm{Q} 0.02 \%$ for cases marked as $\mathrm{C} 1$ and $\mathrm{C} 2$. The safe freeboard was obtained, i.e., for the case $\mathrm{C} 1$ equaling $0.87 \mathrm{~m}$ and for case C2 $1.0 \mathrm{~m}$. However, outflow may have a significant impact to the areas below the reservoir due to the high discharge rates, exceeding for both cases $600 \mathrm{~m}^{3} \mathrm{~s}^{-1}$.

Results (Fig. 11) for case C3 (control wave routing) show that the maximum water level in the reservoir is much below the adequate freeboard limit (1.90 versus 0.30 ). The outflow is also less than in cases $\mathrm{C} 1$ and $\mathrm{C} 2$, equaling $491.53 \mathrm{~m}^{3} \mathrm{~s}^{-1}$ but still dangerous for the adjacent areas.

The calculation results indicate that only the control wave causes a hazard when passing through the reservoir, which corroborates the design assumptions.

It should be noted that if the reservoir is almost completely emptied, this significantly affects the degree of reduction of the flood wave and the shaping of the maximum water pool level in the reservoir. Considering the relatively quick spillage of water onto the adjacent areas, resulting in flood losses, this fact may play a significant role in the protection of the areas lying downstream. On the basis of the analysis of the flood routing through the reservoir for different flow values and water pool levels in the river channel situated downstream, the authors propose the following way of managing the reservoir:

a) When the warning stage is exceeded at Krasków station, proactively discharge through the middle bottom outlet conduit at a rate below $10 \mathrm{~m}^{3} \mathrm{~s}^{-1}$, which ought to start outflow.

b) When the alert stage is exceeded at Krasków station, the middle bottom outlet conduit ought to be closed and the two outer bottom outlet conduits should be in operation without exceeding discharge $\mathrm{Q}=40 \mathrm{~m}^{3} \mathrm{~s}^{-1}$, with continuously controlling the increase of water storage in the reservoir.

c) When the water pool level in the reservoir keeps rising, gradually increase the water outflow up to flood flow $\mathrm{Q}=120 \mathrm{~m}^{3} \mathrm{~s}^{-1}$, and in the case when increasing reservoir filling is limited, gradually limit the discharge commensurately with the inflow.

d) When additional increase in the rate of inflow is forecast, begin to gradually close the bottom outlets and simultaneously change over to water discharge through the surface spillway.

e) When the reservoir filling pool level quickly increases above NPL $=170.60 \mathrm{~m}$ a.s.l., all the overflow structures should be opened; the control of the outflow from the reservoir is lost.

\section{Conclusions}

Climate change can influence the evaluation of probable maximum floods (PMFs), and after this dam safety estimation. This paper identifies the verifying method of dam crest overtopping risk, in the conditions of enlarging the maximal calculated discharges. Peaks of the calculated discharges were determined on the hydrological observation basis in the gauging station close to Mietków Reservoir. The wave volume necessary for analyzing the flood routing through the reservoir was determined on the basis of the 6 historical unit hydrographs that were preliminary normalized for hypothetical wave hydrograph shaping and for matching the peaks.

Flood routing analysis through the reservoir was numerically performed for 6 scenarios of 2 calculated discharges - designing and control ones, and for 3 starting reservoir water pool levels: the lowest pool level (dead storage level), the spillway crest level when the flap gate is fully opened, and the normal pool level. In numerical analysis the situation when one overflow span and one bottom outlet conduit are closed was taken into consideration (only for designing discharge).

The computer simulations of flood wave routing with peaks corresponding to the design flows through the reservoir and its overflow structures showed that it is possible to safely pass the design wave and the control wave (but without adding the estimation error), at no hazard of dam crest overtopping. For the design flow at one bottom outlet conduit and one overflow span closed and the initial reservoir pool level of $170.60 \mathrm{~m}$ a.s.l, the calculated maximum water pool level in the reservoir is $173.67 \mathrm{~m}$ a.s.l., slightly exceeding the assumed maximum design water pool level Max PL $=173.60 \mathrm{~m}$ a.s.l. At this flow the dam crest elevation above the maximum water level amounts to $73 \mathrm{~cm}$, which does not agree with the required safe freeboard of $130 \mathrm{~cm}$. In the other flow and initial reservoir water pool level cases, the regulation flood wave flow requirements are satisfied. 
The calculations carried out for the case of the control wave including mean estimation error showed that it is not possible to safely pass this flow through the reservoir. In order to meet this requirement it would be necessary to increase the reservoir's flow capacity, e.g., by adding an emergency overflow.

The illustrated example of a reservoir in Mietków clearly indicates the need to verify capacity of the existing spillway, because everybody must remember that despite the high costs of modernizing the dam, the losses caused by its catastrophic failure could be significantly greater.

\section{Conflict of Interest}

The authors declare no conflict of interest.

\section{References}

1. KANG B., LEE S.-J., KANG D.-H., KIM Y.-O. A flood risk projection for Yongdam dam against future climate change. J. Hydro. Environ. Res. 1, 118, 2007.

2. JOTHITYANGKOON C., HIRUNTEEYAKUL C., BOONRAWD K., SIVAPALAN M. Assessing the impact of climate and land use changes on extreme floods in a large tropical catchment. J. Hydrol. 490, 88, 2013.

3. LEE B.-S., YOU G. J.-Y. An assessment of long-term overtopping risk and optimal termination time ofdam under climate change. J. Environ. Manage. 121, 57, 2013.

4. KIM B., SHIN S.C., KIM D.Y. A resilience loss assessment framework for evaluating flood-control dam safety upgrades. Nat. Hazards. 86, 805, 2017.

5. SABBAGH-YAZDI S-R., JAMSHIDI M., Depth-Averaged Hydrodynamic Model for Gradual Breaching. J. Hydraul. Eng. 139 (6), 580, 2013.

6. KIM B., SHIN S., KIM D. A resilience loss assessment framework for evaluating flood-control dam safety upgrades. Nat. Hazards. 86, 805, 2017.

7. BOCCHIOLA D., ROSSO R. Safety of Italian dams in the face of flood hazard. Adv. Water Resour. 71, 23, 2014.

8. KIRSHEN P., CAPUTO L., VOGEL R.M., MATHISEN P., ROSNER A., RENAUD T. Adapting urban frastructure to climate change: A drainage case study. J. Water Resour. Plan. Manage. 141 (4), 1, 2015.

9. ZHANG S., TAN Y. Risk assessment of earth dam overtopping and its application research. Nat. Hazards, 74 (2), 717, 2014.

10. CLEARY P. W., PRAKASH M., MEAD S., LEMIALE V., ROBINSON G.K., YE F., OUYANG S., TANG $X$. A scenario-based risk framework for determining consequences of different failure modes of earth dams. Nat. Hazards. 75,1489, 2015.
11. ZHANG S., TAN Y. Risk assessment of earth dam overtopping and its application research. Nat Hazards. 74, 717, 2014.

12. YIGZAW W., HOSSAIN F., KALYANAPU A. Impact of Artificial Reservoir Size and Land Use/Land Cover Patterns on Probable Maximum Precipitation and Flood: Case of Folsom Dam on the American River. J. Hydrol. Eng. 18 (9), 1180, 2013.

13. GOODARZI E., LEE T.S., ZIAEI M. Risk and uncertainty analysis for dam overtopping - Case study: The Doroudzan Dam, Iran, J. Hydro. Environ. Res. 8, 50, 2014.

14. RECEANU R., HERTIG J.-A., FALLOT J.-M. The Estimation of PMP and PMF on Alpine Basins in Switzerland. Aerul şi Apa : Componente ale Mediului (Air and Water Components of the Environment). Cluj University Press, 212, 2012.

15. LAGOS-ZÚÑIGA M.A., VARGAS M.X. PMP and PMF estimations in sparsely-gauged Andean basins and climate change projections. Hydrol. Sci. J. - Journal des Sciences Hydrologiques. 59 (11), 2027, 2014.

16. MICOVIC Z., SCHAEFER M.G., TAYLOR G.H. Uncertainty analysis for Probable Maximum Precipitation estimates. J. Hydrol. 521, 360, 2015.

17. GAZDEK W. Assessment of limnigraph data usefulness for determining the hypothetical flood waves with the Cracow method. Journal of Water and Land Development. 21, 71, 2014.

18. MINISTRY OF ENVIRONMENT REGULATION of 20 April 2007 concerning requirements which hydraulic structures and their location should meet, Law Gazette. 86 (579), 2007 [In Polish].

19. MACHAJSKI J., OLEARCZYK D., RĘDOWICZ W. Water management instruction manual for Mietków storage reservoir in km 45+030 of Bystrzyca River, Wrocław, 2010 [In Polish].

20. NOVAK P., MOFFAT A.I.B., NALLURI C., NARAYANAN R. Hydraulic Structures, Taylor \& Francis Publishers, New York, 2007.

21. KHATSURIA R.M. Hydraulics of Spillways and Energy Dissipators, Marcel Dekker Publishers, New York, 2005.

22. INSTITUTE OF METEOROLOGY AND WATER MANAGEMENT. Studies of changes in capacity of Mietków, Dobromierz and Bukówka reservoirs and chemical and biological investigations of bottom sediments in Mietków and Nysa reservoirs. Studies of Mietków reservoir capacity, Centre for Technical Inspection of Dams, Warsaw, November 2008 [In Polish].

23. GHOSH S.N. Flood Control and Drainage Engineering, Taylor \& Francis Group, London, 2006.

24. JAIN S.C. Open-channel flow, John Wiley \& Sons, Inc., New York, 2001.

25. GRAHAM W.J. Should Dams Be Modified for The Probable Maximum Flood. J. Am. Water Resour. As. 36, (5), 953, 2000. 
